Wladimir Miakiszew

Uniwersytet Jagielloński

Wydział Filologiczny

Instytut Filologii Wschodniosłowiańskiej

tel. +48126544417

e-mail: władimir.miakiszew@uj.edu.pl

ORCID ID: https://orcid.org/0000-0001-5855-3677

\title{
А могла бы быть Альберика... Неувязка с именованием А. Веспуччи в славянских хрониках XVI века
}

Ключевые слова: XVI vek, Хроника Мартина Бельского, ее переводы на русский язык, ономастика, история топонима Америка.

Эпоха Великих географических открытий коренным образом преобразила географическую картину мира, за относительно короткий отрезок времени площадь известных европейцам территорий земного шара увеличилась более чем в шесть раз. О странствиях путешественников конца XV-го - начала XVI-го вв., в ходе которых западноевропейские первопроходцы прокладывали морские маршруты в Африку, Америку, Азию и Океанию, славяне до поры до времени могли узнавать исключительно из иноязычных источников.

Особой популярностью тогда в Европе пользовались две пионерские публикации 30-40-годов XVI-го столетия, волею случая вышедшие из печати в одном и том же городе - Базеле и затем многократно переиздаваемые. Это сборник Novus orbis regionum ac insularum veteribus incognitarum [Novus orbis 1532], приписываемый Симону Гринеусу ${ }^{1},-$ самая

1 На самом деле сборник составлен немецким теологом Иоганном Гуттихом, а Симон Гринеус - деятель немецкой культуры периода Реформации, издатель античных авторов и теолог, являющийся личным другом Лютера, Меланхтона и Кальвина написал предисловие к этой книге [см.: Казакова 1980, 247]. 
ранняя в Европе книга реалистического представления Великих географических открытий; а также Cosmographia Себастьяна Мюнстера [Cosmographia 1544]. Если первая книга на протяжении двух десятилетий переиздавалась пять раз ${ }^{2}$, о необыкновенной востребованности сочинения Мюнстера говорит факт 24-кратной перепечатки только до конца столетия - как на языке оригинала (немецком), так и в переводах на латынь, французский, итальянский и английский.

Именно эти два источника вскоре после дебютных публикаций дождались довольно свободных переводов на чешский и польский языки. Чешская версия Космографии Мюнстера появилась в 1554 г. [Kozmograffia 1554]. Инициатор издания - император Фердинанд I - считал, что книга послужит улучшению образованности населения, что в свою очередь связывалось с обновлением христианской церкви в Чехии и предотвращением распространения ереси. Не случайно расходы на публикацию взял на себя пражский архиепископ Ян Пухов, а его племянник Зикмунд из Пухова перевел и отредактировал книгу, дополнив ее материалами из других источников [см.: Freidhof, 1988, 451]. В Польше с опорой на сведения, изложенные немецкими гуманистами, первым взялся рассказать о путешествиях мореплавателей Мартин Бельский (ок. 1495-1575) - автор единственного в старопольской словесности труда по общей истории, известного как Kronika wszystkiego świata.

Если в первом ее издании (1551) имеется только небольшое упоминание о географических открытиях, то уже в следующих - расширенных и видоизмененных (1554 и 1564) - одна из книг (4-я во 2-м издании и 10-я в третьем) рассказывает "о wyspach morskich, nowonalezionych, które mogą być rzeczone Świat nowy, iż nie były znajome nigdy starym ludziom, żeglarzom, kupcom albo też i astronomom, tak na wschód słońca, jako i na zachód, na północy, takież na południe, i przez meże, na wodzie sprawne a biegłe w gwiazdarskich naukach, którzy byli: napierwej Krysztof Kolumbus, Pinzonus, Aloizius, Petrus Alonzus, Kadamustus, Amerykus Wespucius, Ludowikus Wartomannus, Portugalczycy, Lusitani i drudzy; też o Kalekucie, wielkim porcie na wschód słońca, i o innych krainach w Indyej" [Bielski 1564, list 440v].

Представляя собой в полном смысле слова энциклопедию исторических и географических знаний того времени, Хроника всего света получила широкое распространение не только в Речи Посполитой,

2 Сборник трижды выходил в Базеле - в 1532, 1537 и 1555 гг.; в 1532 г. он был переиздан в Париже; в 1534 г. - в Страсбурге в переводе на немецкий язык. 
но и у ее восточных соседей [см.: Пташицкий 1905, 372-380]. Самое полное 3-е издание книги переводят на белорусский и русский языки (в 1565-1568, 1584 гг. и на рубеже XVI-го и XVII-го веков). Эти переводы переписывают и, что особенно важно, используют в восточнославянских Хронографах [см.: Соболевский 1903, 53-56].

Материалом для рассмотрения в настоящей статье стали списки перевода на русский язык 10-й книги Хроники... Бельского. Они представляют одну и ту же переводческую редакцию, но самую раннюю рукопись, хранящуюся в Синодальном собрании ГИМа (Синод., № 113) ${ }^{3}$, можно, судя по водяным знакам, датировать концом XVI-го века, в то время как два "петербургских" списка (БАН, Арх. С. № 135 [2 тома] и ГПБ, F.IV.162) увидели свет как копии "синодальной" рукописи столетием позже ${ }^{4}$.

В само́й польскоязычной хронике, равно как в ее довольно точном русском переводе последовательность великих открытий излагается в основном с опорой на их хронологию - она отражается в воспроизведенном выше очень громоздком названии книги. Повествование начинается с раздела о том, как Христофор Колумб осуществлял свои планы “извłдать и осмотрить мłста незнаемыя", потом речь идет "о Петрғ Аленсусқ, какъ нашоль новые стороны и людей, которыхъ мудрецы не писали въ своихъ книгах нигды", далее "о Пизонусқ которой kздиль таковож по морю на полдень...", следом описывается как "Алберикус Веспузиус ишпанъ ... нашоль стран множество новых и незнаемыхъ", очередной раздел посвящен рассказу "о португалскихъ людехъ, которые фздили искать новыхъ сторонъ на востокъ солнца", потом следует пространное изложение "о поход' Аммерикуса Веспуцыя", а точнее о четырех его походах - двух на службе "Фердинанда короля Ишпанского" и двух "короля Емануила португалского" ...

Но позвольте, выше уже упоминался Веспуччи, только не Америк, а Альберик, при этом описание приключений обоих мореплавателей разделено вставкой с изложением заслуг "португалскихъ людей", в том числе великого Магеллана.

3 Предлагаемая в монографии Н. А. Казаковой датировка рукописи - середина XVII в. - представляется неверной [см.: Казакова 1980, 240].

4 Во втором томе Хроники... из Архангельского собрания приводится дата составления списка - 1698 г. с указанием на то, что это "древних преводников самый просторечивый превод с полска языка на русский простый глагол" (Библиотека РАН, Арханг. С. 135, т. II, л. 5). 
Что кроется за рассказом о плаваниях Альберика - сведения о странствиях малоизвестного мореплавателя (скажем, родственника флорентийского путешественника, в честь которого названа Америка) или какое-то недоразумение?

Сам текст рукописи ответа на этот вопрос не дает. Сравнение хронологии экспедиций Альберика и Америка обнаруживает одну точку соприкосновения: мореплавание "Алберикуса" приходится на 1501-й год, в это же время состоялся "третий походъ Аммерикуса Веспуцыуса" ${ }^{5}$. Вместе с тем в представлении маршрута путешествий, описаниях приключений "Веспуцыусов" параллелей уже не обнаруживается. Альберик "пошоль ... изъ мғста Лисибони на море къ полуденнымъ странамъ на трех кораблехъ ... і впервые приплыль до острова Канарїи, и потомъ къ Сигритомъ. И потом до острову которой называютъ Капуть Вириде. ... И опять пошли въ далекое мłсто которое прозываютъ Полеантарь Тикум, а по нашему языку толкуется звтзды которыхъ мы мало видаемъ на западъ солнца, и пошли вłтромъ которой зовется Еурус. И тамо три месяцы плавали ... I вышли ис корабля на берегъ, а тамо та земля от тое страны гдњ Капуть Виреде. $\neq$ Д. [4000] версть" (л. 692-692об.). Америк же, отправившись также "из Лисибонїи плыль морем которое зовутъ море Аляндикум. И пришли на мњсто гдъ равен день с нощїю. ... И потомъ пришли до иной земли. И тамо прибылного ничего не нашли, и потомъ дале еще шли на полдень. ... и плавали по морю просто. И оттуду пошли до земли мурынской (африканской - В. М.), и тамо набрали себъ людей всяким образомъ, и привезли к себł до Лисибону за одно диво на свłт k” (л. 701об.-702об.). В описании похода Альберика очень живописно представлены бедствия, которые пришлось претерпеть на пути "туда": члены экипажей "не могли вид $\mathbf{k}$ ни ни земли ни берега и были въ велиц $\mathbf{k и ̆ ~ п е ч а л и ~ и ~ с к о р б и , ~ ч т о ~}$ не чаяли себъ и въ свою землю возвращенїя, что на нихъ были великїе притчи, и страхи приходили многїя, что у них не мог ни един ни сказати, ни исписати, і в томъ походъ у нихъ через сорокъ дней было тако

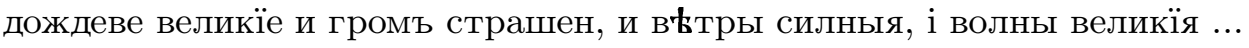
А у нихъ уже на короблихь (sic) не стало ни воды ни дровъ ни хлњба, и не могли уже болши того стерптти великїя нужды. ... А уже были i в часахъ і в забитїи см'кшалися, и потому не могли вид'тти подлинно дорогъ на море куды имъ поити" (л. 692-692об.). Вместе с тем на той

5 Сам мореплаватель датирует свои "походы" 1497, 1499, 1501 и 1503 гг., однако достоверность первого и четвертого путешествий у современных исследователей вызывает большие сомнения. 
земле, где путешественники "вышли на остров велми имъ радостны были, и приняли ихъ с радостїю. ... А рыб тамо множество, а недруговъ у них (туземцев - В. М.) никоторых нътъ развће sвћрей ядовитых, и потому онь в льсъ не ходять, а овощу и коренья ис которого хльбъ пекутъ у нихъ множество много, а злата и жемчюгу, и каменья драгово також много, и птицъ и иных дивныхъ вещей несказанных в той странь множество, и уподобися то мњсто раю, которой быль на земли" (л. 692, 693об.). В рассказе же о третьем походе Америка на погодные условия мореплавателям пришлось сетовать лишь на обратном пути “і впали въ великой страх от вњтра, что и паруса всњ опустили, и плавали по морю просто" (л. 702об.), тогда как отношения с аборигенами в новооткрытых землях представляются здесь как, мягко говоря, не сложившиеся: “і вышли тł люди до португальцовъ на морской берегъ. I вышли к нимъ два португаца, чтобы имъ свњдать какая себњ прибыль въ ихъ стороны, и ходячи въ их стороны хотыли возвратитися к своимъ на корабль въ пятой день, і в кораблехъ дожидаяся ихъ восмь дней. А онњ не бывали. А в ту осмь дней того острова люди безпрестани з берега не сходили по вся дни, ... И португальскїе люди к нимъ послали ис корабля одного человфка таковоже нага какъ и онь наги, и ты жены учали по тłлу его руками трепля дрочить, и дивовалися его тьлу, а тамо люди острова того тыломъ черны, и одна жена вышед из нихъ, и ударивъ того португалца кїемъ ззади, и тоть челов а иные его уже мертваго ухватя за ноги и поволокли к себъ. И португалцы учали по нихъ стрыляти из четырехъ пушекъ. И онњ от пушечново гласа розбњжалися по льсу а ты жены того молодца розсњкли на мłлкїе части, а португалцы то сами видыли. И таковож тł островичи показывали португалцамъ знаки, что и тłхъ прежнихъ дву челов $\mathbf{k} ъ$ оныже сь $\mathbf{k} л$ и португалскїе люди часто въ великїя шкоты впадали. И пошли оттуду прочь без всякаго отмщенїя" (л. 702-702об.).

Совершенно очевидно, что перед нами два разных рассказа. И тем не менее речь идет об одной и той же экспедиции, которой руководил один и тот же человек, известный нам ныне как Америго (или Америко) Веспуччи (1454-1512).

Чем объяснить столь наглядные разночтения в именовании мореплавателя, конечно же, сбивавшие читателя с толку? Что это - переводческая ошибка? Отнюдь нет. Хотя русскому “толмачу" свойственна определенная вольность в трактовке имен собственных (а в тексте рукописи фигурируют сотни дотоле неизвестных русскому языку названий - особенно топонимов), в данном случае русскоязычная версия строго следует польскому оригиналу. В труде Бельского соответству- 
ющие разделы озаглавлены: Iako Alberykus Wespucyus Hiszpan / żegłowat do nieznaiomych krain и $O$ żegłowaniu Amerykusa Wespucya ${ }^{6}$.

Но и автор Хроники... не был инициатором путиницы. Как уже выше отмечалось, исследуемая 10-я книга его сочинения представляет собой сокращенное и отчасти переработанное изложение сведений из более ранних западноевропейских источников.

В свое время польский историк литературы Игнацы Хжановский определил, что на материалах сборника Novus orbis... построены восемь разделов десятой книги Хроники... Бельского (I-IV, VI-IX - именно здесь содержится описание путешествий в Америку, Африку и Азию) и лишь один раздел ( $\mathrm{V}$-й, здесь повествуется о плавании Магеллана) имеет своим источником Космографию Мюнстера [Chrzanowski 1907, 67, 121-122]. Нас интересуют фрагменты книги, рассказывающие о путешествиях Веспуччи, а это IV-й и VI-й разделы, они-то и легли в основу изложения Бельского. Так вот материалы Novus orbis... также отражают вариативность при передаче имени Веспуччи: Alberici Vesputii navigationum epitome и Americi Vesputii navigationes $I I I I^{7}$.

Продолжаем распутывать клубок дальше. В анонимной антологии португальских экспеций Paesi novamente retrovati et novo mondo da Alberico Vesputio Florentino intitulato 8 (книга вышла в свет в 1507-м году на итальянском языке и потом до 1516-го года переиздавалась на латинском, немецком и французском) открытие Нового Света связывается с именем Альберико Веспуччи. Другая книга, опубликованная в том же

\footnotetext{
6 Оглавление к книге может быть представлено следующим образом: I. O żeglowaniu Krzysztofa Kolumbusa (k. 440v), II. Iako Petrus Alonsus nalazł nowe krainy światu nieznaiome (443v), III. Iako Pinzonus towarzysz Kolumbusow szukał nowych krain na południe (444), IV. Iako Alberykus Wespucyus Hiszpan / żegłowat do nieznaiomych krain $(444 \mathrm{v})$, V. Iako Portugalczycy żegłowali na wschod slońca szukaiąc nowych krain / ieszcze swiatu nieznaiomych (445), VI. O żegłowaniu Amerykusa Wespucya (446v), VII. Iako krol Portugalski Emanuel poraźił Maury / y wźiął niektore Krainy w Indyey (448), VIII. Iako Aloizyus Kadamustus żeglował do Nigrytow / tho iest do Murzynow ludu nieznaiomego / sam pisze o sobie (449), O krolestwie Senege y Azenagiyskich ludźiech (449v), [wyprawy] Piotra rzeczonego Aliares... (452v)...

7 Оглавление: I. Aloysii Cadamusti navigatio ad terras ignotas, II. Christophori Columbi navigatio (s. 50), III. Petri Alonzi navigatio (115), IV. Pinzoni navigatio (119), V. Alberici Vesputii navigationum epitome (122), VI. Petri Aliaris navigationis... opusculum, Josephi Indi navigationes (130), VII. Americi Vesputii navigationes IIII (155), VIII. Epistola Emmanuelis regis Portugaliae ad Leonem X, de victoriis habitis in India et Malacha (184)...

8 Автором сочинения считается не Франкансоне де-Монтальбоддо (Fracanzio da Montalboddo), как сначала думали, а венецианский космограф и картограф Алессандро Цорци [см.: Америго Веспуччи 1890, 627].
} 
самом 1507-м году во французском Сен-Дье, в своем заглавии ссылается уже на деятельность Америко: Cosmographiae Introductio. Cum quibusdam geometriae ac astronomiae principiis ad earn rem necessariis. Insuper quatuor Americi Vespucii navigationes ${ }^{9}$. В начале 1505-го года Колумб в своем письме сыну также именует Веспуччи как Америго, называя его “очень достойным человеком" [см.: Цетлин 1971, 340].

Таким образом, практика вариантного именования Веспуччи восходит еще к временам его жизни. А объяснение казуса находим в главном источнике сведений о приключениях знаменитого мореплавателя - его письмах.

Как известно, мировую славу Веспуччи принес его третий поход, когда путешественник в своем мнении, да и глазах современников "открыл Новый Свет" 10. О подробностях плавания к берегам Бразилии (май 1501 - сентябрь 1502) мы узнаем из двух посланий флорентийца. Первое из них написанно в конце 1502 или в марте - апреле 1503 года к Лоренцо ди Пьеру Франческо дель Медичи ${ }^{11}$ :

Приведем фрагменты из текста перевода, а, вернее, русскоязычной версии нескольких сохранившихся переводов ${ }^{12}$, чтобы лишний раз убедиться, что в основе рассматриваемой истории из Хроники... Бельского лежал текст самого Веспуччи - пропущенный, правда, через призму пересказов многочисленных посредников.

9 Введение в космографию с необходимьми для оной основами геометрии и астрономии. K сему четыре плавания Америго Веспучии. Полагают, что предложение назвать Новый Свет Америкой, то есть страной Америго, было сделано впервые книгопродавцем Мартином Вальдземюллером именно в этой книге.

10 О самонадеянной позиции Америго можно судить по отрывку из его письма: “Эти страны следует назвать Новым Светом. ... Большая часть их (древних авторов - В. М.) говорила бы, что дальше равноденственной линии - по направлению к югу нет никаного континента, ... если бы кто-нибудь из них утверждал, что там находится континент, они отрицали бы, что эта земля обитаема. ... Мое последнее плавание доказало это, так как я нашел в этих южных областях континент с более многочисленными племенами и более разнообразной фауной, чем в нашей Европе, Азии или Африке, и, сверх того, с более умеренным и приятным климатом, чем в любой другой стране, нам известной" [Письма 1971, 342].

11 Лоренцо ди Пьер Франческе дель Медичи (1453-1505) - итальянский банкир, старый друг и покровитель Веспуччи. Был послом Флоренции при дворе Карла VIII французского.

12 "Послание было написано первоначально, возможно, на итальянском языке. Подлинник был утерян, и сегодня известен лишь латинский перевод, сделанный с итальянского перевода, произведенного, в свою очередь, с испанского. В конце письма указано, что оно является переводом: «Ex Italica in Latinam Linguam iocundus niterpres hanc epistolam vertit». Вероятно, латинский текст был напечатан три или четыре раза в 1503 году (хотя первое датированное издание не появлялось до 1504 года) и несколько раз в 1504-1505 годах" [Письма 1971, 340]. 


\begin{tabular}{|c|c|}
\hline $\begin{array}{c}\text { Письмо А. Веспуччи к Лоренио } \\
\text { ди Пьеру Франческо дель Медичи } \\
\text { (конец } 1502 \text { или март-апрель 1503) }\end{array}$ & $\begin{array}{c}\text { Хроника... Бельского в переводе на } \\
\text { русский язык (конец XVI века) рассказ } \\
\text { о походе Альберикуса Веспуцыуса }\end{array}$ \\
\hline $\begin{array}{l}\text { (с. 345) Все жители, и тот и другой пол, } \\
\text { ходят обнаженными, не прикрывая ни- } \\
\text { какой части тела. Как выходят из утро- } \\
\text { бы матери, так до самой смерти и хо- } \\
\text { дят. У них стройные и большие фигу- } \\
\text { ры, хорошо и пропорционально сложен- } \\
\text { ные, с цветом кожи, приближающимяя } \\
\text { к красноватому. Я думаю, что это про- } \\
\text { исходит у них потому, что они, расха- } \\
\text { живая нагими, загорают на солнце. На } \\
\text { голове у них великолепные черные кос- } \\
\text { матые волосы. У них приятное лицо, } \\
\text { которое они, однако, сами себе уроду-- } \\
\text { ют. Ибо они прокалывают себе и ще- } \\
\text { ки, и губы, и ноздри, и уши. И ты не } \\
\text { думай, что эти отверстия малые и что } \\
\text { они имеют их тольно одно. Ибо я видел } \\
\text { некоторых людей, имеющих на одном } \\
\text { лице семь дыр, из которых любая бы- } \\
\text { ла способна вместить сливу. Они вты- } \\
\text { кают себе в эти отверстия очень краси- } \\
\text { вые голубые камни, мрамор, кристаллы } \\
\text { или алебастр, а также очень белые ко- } \\
\text { сти и другие предметы, художественно } \\
\text { оформленные согласно их обычаю. Ес- } \\
\text { ли бы ты видел это необыкновенное де- } \\
\text { ло, подобное чуду, ты был бы, конеч- } \\
\text { но, изумлен, что человек имеет в щеке } \\
\text { один, а в губах семь камней, из которых } \\
\text { некоторые величиной с половину ладо- } \\
\text { ни. Ибо часто я определял и находил, } \\
\text { что семь таких камней весят шестна- } \\
\text { дцать унции, и, кроме того, в каждом } \\
\text { из ушей имеются по три пробитых от- } \\
\text { верстия, несущих другие камни, вися- } \\
\text { щие на кольцах. Таков обычай у одних } \\
\text { мужчин, ибо женщины не прокалывают } \\
\text { себе лица, но только уши. }\end{array}$ & 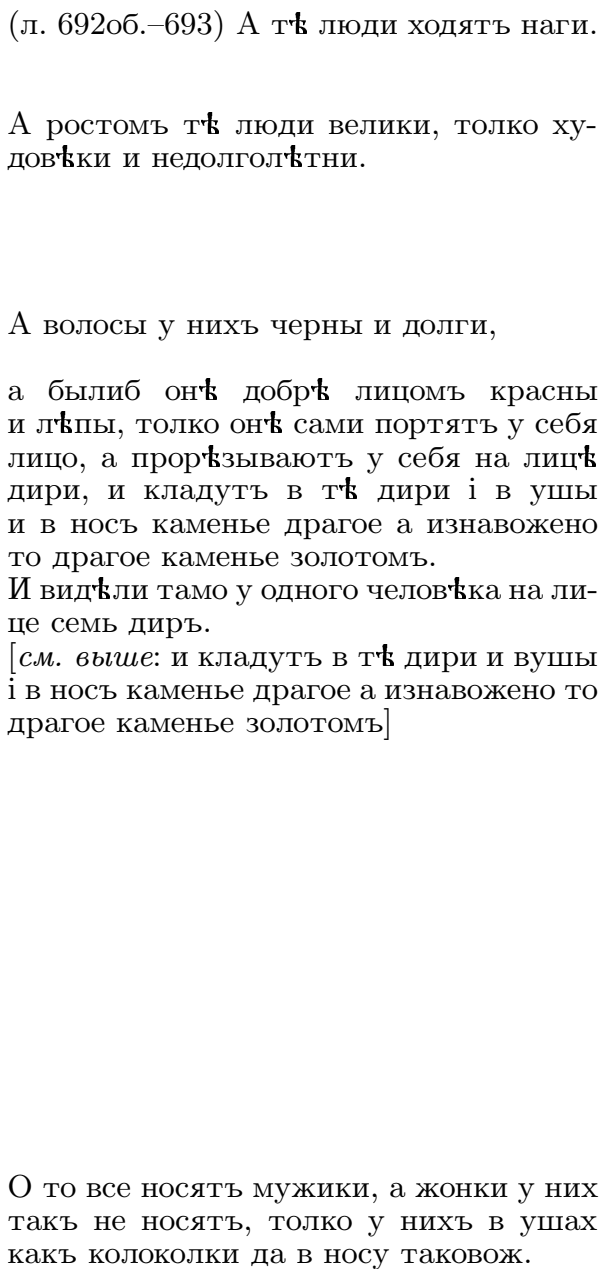 \\
\hline
\end{tabular}

Второе более обширное письмо Веспуччи, относящееся к сентябрю 1504 года, адресовано товарищу детства мореплавателя, знатному флорентийцу и гонфалоньеру республики Флоренции Пьетро Содерини [Письма 1971, 343-375 $]^{13}$.

13 "Не было ясным, на каком языке оно было написано первоначально: на итальянском или на латинском. Латинский текст впервые был опубликован в апреле 1507 года в очень сейчас редком издании Введение в космографию Вальдзеемюллера. ... в латинском варианте сообщается, что он является переводом с французского, который, 


\begin{tabular}{|c|c|}
\hline $\begin{array}{c}\text { Письмо А. Веспуччи к Пьетро Содерини } \\
\text { гонфалоньеру республики Флоренчии } \\
\text { (4 сентября } 1504 \text { года) }\end{array}$ & $\begin{array}{c}\text { Хроника... Бельского в переводе на } \\
\text { русский язык (конец XVI века) рассказ } \\
\text { о походе Аммеририкуса Веспуцыуса }\end{array}$ \\
\hline $\begin{array}{l}\text { Туземцы не имели никаких видов пи- } \\
\text { щи и корней, как на материке. Они пи- } \\
\text { тались рыбой, которую ловили в море, } \\
\text { а она была в огромном изобилии. [...] } \\
\text { У них не было ни деревень, ни домов, } \\
\text { ни хижин, за тем исключением, что они } \\
\text { селились под деревьями, защищавшми } \\
\text { их от солнца, но не от воды. } \\
\text { Я полагаю, что на этом острове дожди } \\
\text { шли очень редко. } \\
{[\text {...] Видя, что здесь не было ничего вы- }} \\
\text { годного для нас, мы отправились от- } \\
\text { сюда, взяв курс на другой остров. Мы } \\
\text { вскоре обнаружили, что на нем обита- } \\
\text { ло племя очень высоких людей. [...] Идя } \\
\text { по берегу, мы заметили очень большие } \\
\text { человеческие следы на песке и рассуди- } \\
\text { ли, что, если и другие члены тела бы- } \\
\text { ли соответственного размера, туземцы } \\
\text { должны быть очень крупными людь- } \\
\text { ми [...] Пройдя почти целый лиг, мы } \\
\text { увидели в долине пять их хижин, ка- } \\
\text { завшихся необитаемыми. Мы направи- } \\
\text { лись к ним, но нашли там только пять } \\
\text { женщин: двух старух и трех девушек. } \\
\text { Они были столь высоки ростом, что } \\
\text { мы смотрели на них с изумлением. Ко- } \\
\text { гда они увидели нас, их охватил та- } \\
\text { кой ужас, что им не хватило даже духа }\end{array}$ & 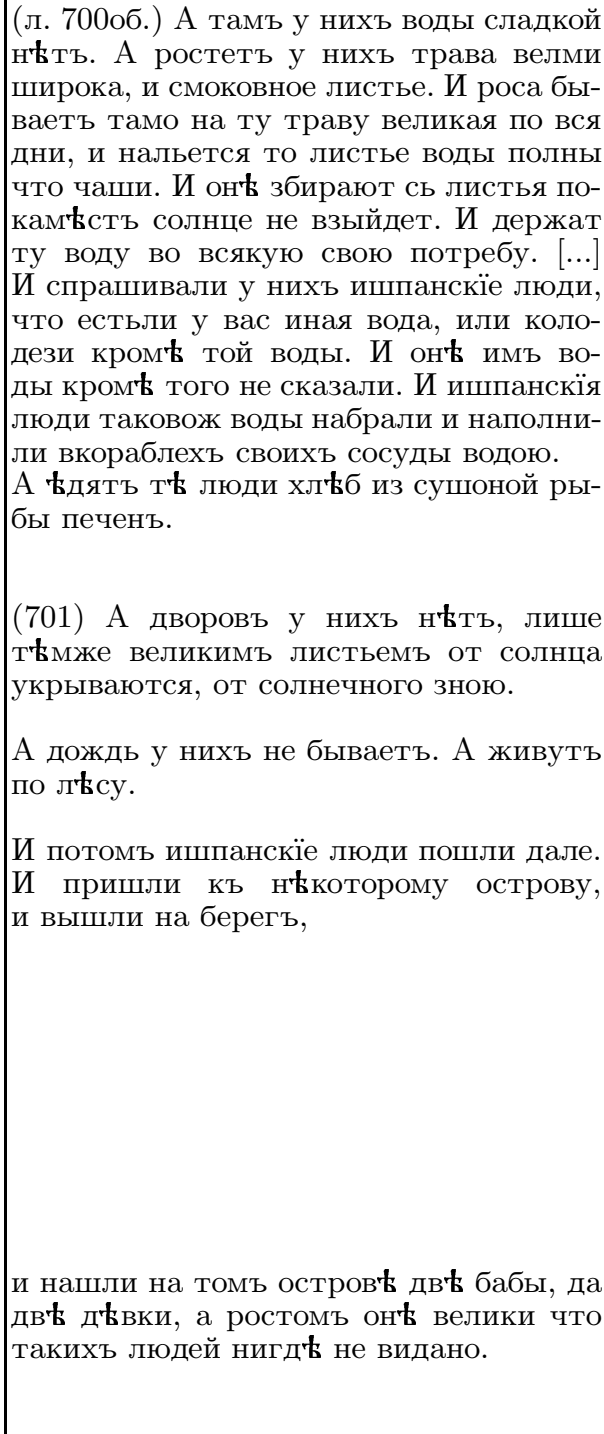 \\
\hline
\end{tabular}

в свою очередь, был сделан с итальянского, в итальянском же варианте письма не только не говорится ничего подобного, но и самый язык его, полный чужеземных испанских оборотов, указывает на то, что оно было первоначально написано кем-то, кто, как Веспуччи, когда он писал его в 1504 году, насчитывал уже четырнадцать лет, проведенных вне Италии и большую часть времени - в Испании" [Письма 1971, 340]. 


\begin{tabular}{|c|c|}
\hline $\begin{array}{c}\text { Письмо А. Веспуччи к Пьетро Содерини } \\
\text { гонфалоньеру республики Флоренчии } \\
\text { (4 сентября } 1504 \text { года) }\end{array}$ & $\begin{array}{c}\text { Хроника... Бельского в переводе на } \\
\text { русский язык (конец XVI века) рассказ } \\
\text { о походе Аммеририкуса Веспуцыуса }\end{array}$ \\
\hline $\begin{array}{l}\text { убежать. [...] Мы хотели забрать с со- } \\
\text { бою трех девушек силой и увезти в Ка- } \\
\text { стилию как чудо. В то время как мы } \\
\text { так рассуждали, в дом начали входить } \\
\text { взрослые мужчины. Их было } 36 \text { чело- } \\
\text { век. Они были гораздо выше, чем жен- } \\
\text { щины, и так хорошо сложены, что было } \\
\text { приятно смотреть на них. Они поверг- } \\
\text { ли нас в такой страх, что мы предпо- } \\
\text { чли бы находиться на наших кораблях, } \\
\text { чем в обществе таких людей. Они име- } \\
\text { ли с собой очень большие луки и стре- } \\
\text { лы и несли большие шишковатые ду- } \\
\text { бинки. [...] Мы решили тихо уйти из их } \\
\text { дома и направиться к кораблям. Так мы } \\
\text { и поступили и, выйдя из дома, пошли } \\
\text { к кораблям. Однако дикари шли за на- } \\
\text { ми еледом, находясь всегда на расстоя- } \\
\text { нии броска камня и разговаривая меж- } \\
\text { ду собой. Я полагаю, они боялись нас не } \\
\text { меньше, чем мы их, потому что, когда } \\
\text { мы иногда останавливались, они дела- } \\
\text { ли то же самое, не подходя ближе, до } \\
\text { тех пор пока мы не достигли берега, где } \\
\text { нас ожидали лодки. } \\
\text { Мы сели в них и, когда находились уже } \\
\text { на некотором расстоянии от берега, ви-- } \\
\text { дели, как они плясали на нем, посылая } \\
\text { в нас много стрел. Но мы уже мало бо- } \\
\text { ялись их теперь и произвели два вы- } \\
\text { стрела по ним из пушек, больше для } \\
\text { того чтобы напугать их, чем попасть } \\
\text { в них. При выстрелах все они побежали } \\
\text { на холм. [... } \\
\text { Я называю тот остров Островом гиган- } \\
\text { тов из-за большого роста этих людей. }\end{array}$ & 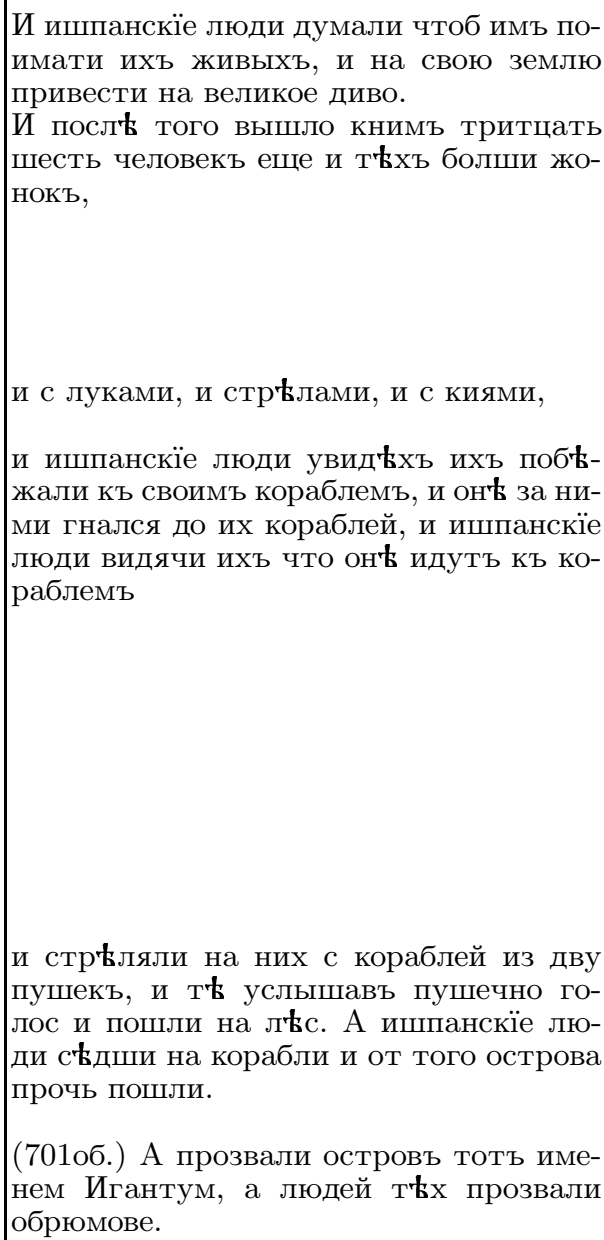 \\
\hline
\end{tabular}

По времени написания тексты частных посланий Веспуччи и Хроники... Бельского разделяет целое столетие, на протяжении которого в передаче содержания писем мореплавателя участвовала целая цепочка разноязычных посредников, между тем эффект "испорченного телефона", как можно убедиться, здесь почти не проявляется.

Самым важным для нас обстоятельством является то, что первое из процитированных писем подписано Альберико, а второе Америго Веспуччи, и этой разницы придерживались позднее авторы, ссылающиеся по горячим следам на приводимые мореплавателем сведения. 
Сразу отметем как ошибочное неоднократно звучавшее в литературе вопроса суждение, будто "по-латыни имя Америго передавалось как Альберик" [см., напр.: Лалаянц 1985, 37]. У этих сложных по словообразовательной структуре антропонимов разное происхождение: Америго восходит к нем. Emmerich - если первый элемент этого имени интерпретируется этимологами по-разному: от ermen 'целостность, универсальность', amal 'работа', heim 'дом, родина', второй однозначно соотносится с ric 'сила, власть'; Альберик также является германизмом (cp. Alberich), включающим элемент ric 'сила, власть', но соединяется он с корнем alf 'эльф' - Альберих был королем гномов в немецкой мифологии [см.: Förstemann 1900, 953, 71].

Догадывался ли Бельский о замешательстве с именами мореплавателя - неизвестно, но в отличие от предшественников он ввел в свой текст (а переводчик на русский перевел) утверждение, которое можно расценить как попытку связать концы с концами: "Amerykus rzeczony od Ameryki wyspy wielkiey ktora może być liczona za czwartą część swiata / iż ią ten wynalazl" (k. 446v) ${ }^{14}$. По тем временам это было неожиданное заявление - в Польше еще в начале XVI века утвердилась противоположная точка зрения: местные географы Ян из Стобниц и Матэуш Кмита из Шамотул в своих публикациях [Introductio 1512; Joannis de Sacrobosco 1522] сходились в мысли, что "została odkryta wielka ziemia, którą od jej odkrywcy Ameriga nazywają Ameryką, powszechnie zaś zową ją Nowym światem" [Olszewicz 1910, 322]. Выдвинув свой рискованный тезис, донедавна оцениваемый исследователями исключительно как демонстрация "postawienia etymologii na głowę" [Buchwald-Pelcowa 2001, 161], Бельский оказался вовлеченным в затянувшийся на столетия и до конца еще не разрешенный спор о происхождении слова Америка. Более того, время показало, что мнение автора Хроники... сегодня отнюдь не сбрасывается со счетов.

В нашу задачу не входит оценка степени правдоподобия той или этимологической трактовки топонима Америка. Ограничимся лишь простым перечнем главных интерпретаций самого загадочного из названий материков, дабы показать, что ничем тогда не аргументированная догадка Бельского со временем была подкреплена вполне весомыми доводами.

14 В русском переводе: "Аммерикусъ прозванъ именемъ от великого острова Аммерика. А тоть островъ мочно прозвать за четвертую часть св қта. А нашоль тот островъ от (sic) Аммерикус Веспуцыя" (л. 698). 
Помимо хрестоматийной теории, согласно которой заокеанские материки не совсем справедливо были названы Землей Америко по имени того, кто не будучи первооткрывателем, первым описал далекие территории, существует целый ряд концепций обратного толка, представляющих новое именование Веспуччи как благоприобретенное в честь его главной заслуги.

Спустя три с лишним века после Бельского (в 70-е годы XIX века) французский ученый Жюль Марку (Jules Marcou) пытался доказать, что топоним Америка происходит от названия индейского племени амерриков - los Ameriques, проживавших у озера Никарагуа, и что Веспуччи изменил свое первоначальное имя Альберико в честь открытия нового материка [Лалаянц 1985, 37]. Бразильские историки еще в конце того же столетия настаивали на том, что название континента берет начало от имени Марока - верховного божества древних обитателей их страны [Лалаянц 1985, 37]. Французско-американский исследователь Томас Ламбер-де-Сен-Бри (Thomas Lambert de Saint-Bris) своей публикацией 1890 года доказывал, что в Новом Свете к моменту прибытия Колумба уже существовали города и поселения с названиями Амарака, Маракапан, Америокапана [см.: Westphal 2013, 128-129]. Впрочем, и прежде испанский историк Херрес заявлял, что мореплаватели Охед и Веспуччи нашли в 1499 году на берегу нынешней Венесуэлы порт Маракапан, который английским мореплавателем Рэлеем, посетившим Америку в 1584 году, назван в своих донесениях Америокапана [см.: Лалаянц 1985, 37]. Своя версия относительно недавно появилась у англичан. Им представляется, что название континентам дал британский мореплаватель Джон Кабот, который высадился на американский берег в 1497 году - то есть до Веспуччи. Он назвал новооткрытые земли в честь Ричарда Америка, состоятельного купца из Бристоля, который снарядил корабль мореплавателя. Сам факт экспедиции Кабота и источника ее финансирования вроде бы удостоверяется бристольскими летописями [Westphal 2013, 129].

Как видим, все приведенные трактовки будто бы подтверждают правоту предпринятой в далеком XVI веке в Польской Короне пробы связать прозвище (!) Америго с названием обнаруженных за океаном земель, что снимает неувязку с двойным именованием Веспуччи. Однако серьезным, а, может быть, непреодолимым препятствием в логике развития этой концепции, является позднейшая “датировка" утверждения топонима Америка в качестве общеизвестного: Америком Веспуччи именуется в 1504-м году, то есть за несколько лет до того, как это слово начало использоваться в роли названия двух американских кон- 
тинентов и вытеснило из книг и географических карт мира именования: Novus Orbis, Terra dos Papagaios, Isla de Santa Cruz, Brazzil, Indias Occidentals...

Мог ли с учетом всего сказанного Новый свет стать Альберикой? Если брать во внимание разнородные обстоятельства "комедии ошибок" и нагромождения случайностей, из которых была "соткана паутина великого заблуждения" ${ }^{15}$, наверное, да. А еще больше шансов у материка было стать Колумбией или Веспуччией. Но все пошло иначе, давая нам сегодня повод утверждать, что в запутанной истории о том, каким образом Америка получила свое название, ставить точку пока еще рано.

\section{Источники}

[Bielski M.], Kronika. tho iesth, Historya Swiata na sześc wiekow, a cżterzy Monarchie, rozdźielona z rozmaitych Historykow, tak w swiętym pismie Krześćijańskim Zydowskim, iako y Pogańskim, wybierana y na Polski ięzyk wypisana, Kraków 1564.

Cosmographia, Beschreibung aller Lender durch Sebastianum Münsterum, Bazel 1544.

15 Хотя выделенные кавычками слова написаны С. Цвейгом [Цвейг 1963, 398], основные заслуги в деле выяснения обстоятельств сумбурного переплетения недоразумений, приведших к распространению привычного нам названия континента, принадлежат А. Гумбольдту. В своих Критических исследованиях об историческом развитии географических сведений касательно Нового Света немецкий ученый-энциклопедист представил ход событий, сопутствующих присвоению материку имени Америго Веспуччи. В 1507 году в Виченце была напечатана антология, содержащая описания португальских экспедиций Кадамосто, Васко да Гамы, Колумба и Веспуччи (по его же письмам). Роковым образом издатель книги назвал ее Mondo novo e paesi nuovamente retrovati da Alberico Vesputio florentino (Новый Cвет и новые страны, открытыье Альберико Веспучии из Флорениии). Содержащаяся в заглавии двусмысленность позволяла думать, будто Веспуччи открыл не только новые страны, но и Новый Свет. В том же году в Сан-Дье (окрестности Страсбурга) реализуется проект восполнения и корректировки единственной на то время классической книги по географии - Космографии Птолемея, чей текст и карты в течение веков считались в Европе непревзойденными и непогрешимыми. Расширение знаний о Вселенной, в том числе за счет открытий мореплавателей, сделало труд Птолемея неактуальным. В основу напечатанной в Сан-Дье книги - Cosmographiae introductio etc., insuper quatuor Americi Vespucii navigationes - был взят тот самый сборник писем, изданный под именем Веспуччи. Книга содержала знаменитую карту Universalis Cosmographia, автор которой Мартин Вальдземюллер и предложил назвать Новый Свет Америкой, "по имени мудрого мужа, открывшего ее". Для пущей убедительности на карте был даже размещен портрет Веспуччи, подписанный "Americi Vespucii". Как сама Cosmographiao introductio.., так и карта Вальдземюллера обратили на себя большое внимание и многократно переиздавались, способствуя все большему распространению нового названия континента [см.: Америго Веспуччи 1890, 627-628; Цвейг 1963, 373-449]. 
Cosmographiae Introductio. Cum quibusdam geometriae ac astronomiae principiis ad earn rem necessariis. Insuper quatuor Americi Vespucii navigationes, [St. Dié] 1507.

Introductio in Ptholomei Cosmographiam Jana ze Stobnicy, Kraków 1512.

Joannis de Sacrobosco astronomii celeberrimi sphericum opusculum, cum licida et familiari expositione per Matthaeum Shamotulien, Kraków 1522.

Kozmograffia Cžeská: To gest wypsánij o položenij Kragin neb Zemij y Obyčegijch Národuow wsseho Swieta a Hystorygij podlé Počtu Leth naněm zběhlých prwé nikdá tak pospolku w žádném Jazyku newidaná, [Praha 1554].

Novus Orbis regionum ac insularum veteribus incognitarum, [Simon Grynaeus], Basel 1532.

Paesi novamente retrovati et novo mondo da Alberico Vesputio Florentino intitulato, Vicenzia 1507.

\section{Литература}

Amerigo Vespučči, 1890, [v:] Ènciklopedičeskij slovar' Brokgauza IEFRONA, t. IA, Sankt-Peterburg, s. 627-628. [Америго Веспуччи, 1890, [в:] Энииклопедический словарь Брокгауза и Ефрона, т. ${ }^{\mathrm{A}}$, Санкт-Петербург, с. 627-628.]

Kazakova N. A., 1980, Zapadnâa Evropa v russkoj pis'mennosti XV-XVI vekov, Leningrad. [Казакова Н. А., 1980, Западная Европа в русской письменности $X V-X V I$ веков, Ленинград.]

Lalaânc I., 1985, Tajny znakomyh nazvanij, "Vokrugsveta" № 6, s. 36-39. [Лaлаянц И., 1985, Тайнь знакомых названий, "Вокруг света" № 6, с. 36-39.]

Pis'ma Amerigo Vespučči, 1971, [v:] Brigantina - 1971, Moskva, s. 343-375. [Пuсbма Америго Веспуччи, 1971, [в:] Бригантина - 1971, Москва, с. 343-375.]

Ptašickij S., 1905, Zapadno-russkie perevody hronik Bel'skogo i Stryjkovskogo, [v:] Novyj sbornik statej po slavânovedeniû, Sankt-Peterburg, s. 372-384. [Пташицкий С., 1905, Западно-русские переводы хроник Бельского и Стрыйковского, [в:] Новый сборник статей по славяноведению, Санкт-Петербург, с. 372-384.]

Sobolevskij A. I., Perevodnaâ literatura Moskovskojrusi XIV-XVII vekov. Bibliografičeskie materialy, Sankt-Peterburg 1903. [Соболевский А. И., Переводная литература Московской Руси XIV-XVII веков. Библиографические материаль, Санкт-Петербург 1903.]

Cvejg S., 1963, Amerigo, [v:] ego že, Sobraniesočinenij v semi tomah, t. 3, Moskva, s. 373-449. [Цвейг С., 1963, Америго, [в:] его же, Собрание сочинений в семи томах, т. 3, Москва, с. 373-449.]

Cetlin M. N., 1971, Predislovie, [v:] Pis'ma Amerigo Vespučči, [v:] Brigantina 1971, Moskva, s. 339-342. [Цетлин М. Н., 1971, Предисловие, [в:] Письма Америго Веспуччи, [в:] Бригантина - 1971, Москва, с. 339-342.]

Buchwald-Pelcowa P., 2001, Marcin Bielski o odkrywaniu nowycg światów, [w:] Wyobraźnia epok dawnich: obrazy - tematy - idee. Materiaty sesji dedykowanej Profesorom Jadwidze i Edmundowi Kotarskim, Bydgoszcz, s. 153-165.

Chrzanowski I., 1907, Marcin Bielski. Studyum literackie, Warszawa. 
Förstemann E., 1900, Altdeutsches namenbuch, Bonn.

Freidhof G., 1988, Sebastian Münsters "Cosmograhpia" und ihre Tschechische Bearbeitung, [w:] Studien zum Humanismus in der Böhmischen Ländern, Köln-Wien, s. 441-466.

Olszewicz B., Pierwsze wiadomości o odkryciu Ameryki w literatirze polskiej, "Ziemia" 21 maja 1910, nr 21, s. 321-323.

Westphal B., 2013, The Plausible World: A Geocritical Approach to Space, Place, and Maps, New York.

IT COULD HAVE BEEN 'ALBERICA'...

INCONSISTENCIES IN A. VESPUCCI'S NAME RENDERING

IN SLAVIC 16TH CENTURY CHRONICLES

S U M M A R Y

Based on the Universal Chronicle (Kronika wszystkiego świata) (1564) by Marcin Bielski and its Russian translations of the $16^{\text {th }}-17^{\text {th }}$ centuries, the paper addresses a description of travels by supposedly two navigators named Vespucci Alberykus and Amerykus Vespucci. The paper consistently looks into the full array of intermediary sources on Vespucci's travels to clear up this misconception and find out finally that its underlying cause were letters by the navigator himself. 